EDITORIAL HEADQUARTERS

Argospine association

25, rue Schweighaeuser, F-67000 Strasbourg FRANCE

President : Prof. Christian Mazel, MD

General secretary : Prof. Pierre Kehr, MD

Treasurer : Alain Graftiaux, MD

EDITORIAL STAFI

Editors in chief :

Christian Mazel, MD

Pierre Kehr, MD

Translator :

Nathalie Richard

Graphic \& visual designer :

Karim Boukarabila : karim@boukarabila.com

Principal assistant editors in chief :

Denis Kaech, MD

Nathalie Richard

ARGOSPINE ASSOCIATION

Managing committee :

Laurent Balabaud, MD

Alain Graftiaux, MD

Stefano Boriani, MD

Jean-Pierre Elsig, MD

Tamas Illes, MD

Dimitrios Korres, MD

Panagiotis Korovessis, MD

Charles-Marc Laager, MD

Robert Melcher, MD

Anca Mitulescu, PhD

Pierre Pries, MD

William Blake Rodgers, MD

Jean-Paul Steib, MD

Wafa Skalli, PhD

Alexandre Templier, PhD

Christopher Ullrich, MD

PRODUCTION

Springer-Verlag France

22, rue de Palestro, F-75002 Paris FRANCE

Director of the Publication :

Guido Zosimo-Landolfo

Publishing Editor :

Claus Roll : claus.rol/@springer.com

Advertising Sales and Partnership Managers : Tanit Pruvost, Karine Pech

CONTACTS

ArgoSpine :

Assitant editor-in-chief and Association secretary

Nathalie Richard : nathalie.richard@argospine.org

Mobile : +33 (0)6 61514568

Contact for Springer France :

www.argospine.org

Advertising Sales assistant and manager

Tanit Pruvost : tanitpruvost@springer.com

Phone : +33 (0)153009870

Karine Pech : karine.pech@springer.com

Phone : +33 (0)1 53009873

ArgoSpine News \& Journal is published 4 times a year by Springer-Verlag. It is sent for free to physicians, surgeons,

researchers and industrial companies on an international scale. Single copy price: $10 €$ for individuals and companies registered on the Argospine list. For new subscriptions, individuals and institutions should contact the Springer subscription department.

\title{
Editorial
}

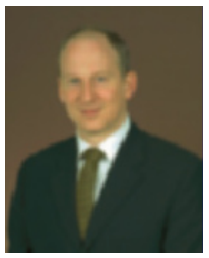

\section{ArgoSpine: not just another meeting}

We have often heard the complaint from spine surgeons that there are "too many spine meetings these days". Our accumulating frequent flyer points support the notion. The Paris-based annual ArgoSpine Symposium is different, however and deserves some distinction from the pack in our view.

principal reason we like this The decidedly scientific meeting is that it takes a multidisciplinary approach to complex spine problems. ArgoSpine meetings normally underscore a scientific theme where multiple pathologies and challenging surgical situations are discussed under that year's central framework.

This year's theme was medical imaging which is a critical topic that rarely gets coverage at your typical spine meeting. The resulting dialogue was an appraisal of tumors, deformity, vascular issues, trauma, infection, C1-C2 instability, degenerative issues, revision surgery and so forth - all under the lens of imaging. The animated and sometimes vigorous exchanges by surgeons, and even eminent radiologists from all over the world, netted some valuable insights that we normally don't get at the typical meetings.

Some of the takeaways were obvious and some were subtle. Examples include the pitfalls in finding pain generators (disc/facet/other ?), selection of optimal imaging modality (soft tissue or bone?), the role of the radiologist (a valued partner or co-culprit in failed back surgery ?), when to image in trauma cases. The list goes on and we were maybe not so surprised to hear how often there is a real difficulty correlating imaging findings to the real clinical condition.

In keeping with the imaging theme, the ArgoSpine thesis award this year went to
Sabina Champain who conducted a multicenter multi-year (2-14 years) retrospective study on over 1000 patient records concerning a variety of degenerative issues. Quantitative software driven analysis of images were useful in assessing long term saggital alignment, spine geometry and kinematics along with (and compared to) pain and quality of life scores. One finding of interest embedded in the study was the possibility that dynamic stabilization devices contribute to the reduction of adjacent level disease. The results also showed the impact of psychosocial factors of the patient's perception of outcome.

All of the points raised at the meeting did pose the question about advancements in imaging technology which the conference unfortunately tended to shy away from. Maybe that's a good thing at the end of the day. All too often, especially in this financial climate, surgeons and hospitals don't often have access to the latest advancements in imaging technology and are forced to work with what is currently available.

From that standpoint, ArgoSpine addressed vital concerns this year. (1)

EDITO BY JOHN MCCORMICK ॥ HEALTHPOINTCAPITAL MANAGING DIRECTOR

This paper is reproduced by kind permission of the author and of our partner,

HealthpointCapital. it was previously published on the website www.healthpointcapital.com 